\title{
Rational vs emotional communication models. Definition parameters of advertising discourses
}

PhD. Cristina González Oñate

University Jaume I-Castellón. Spain. onate@uji.es

ORCID:https://orcid.org/0000-0003-3509-0117

Eduard Farràn Teixidó

Advertising agency La Rosa Visual. Spain. eduardfarranteixido@gmail.com

ORCID: https://orcid.org/0000-0003-1469-3146

Pablo Vázquez Cagiao

Collaborabrands Director. Spain.

p.vazquez@collaborabrands.com

ORCID: https://orcid.org/0000-0003-0813-9624

\begin{abstract}
The new information technology, as well as changes in the consumer, have generated transformations in the strategic advertising focus. Since rational communication focuses on the product, it seeks clarity by articulating benefits and by relying on strategic mechanisms such as Reeves' Unique Selling Proposition (USP). Through this article, we conducted a theoretical review of the resulting rational and emotional communication models from combining different parameters that result in new advertising discourses. For this, we will combine the theory with examples of awarded cases in different Advertising contests to understand the current thin line between the rational and emotional advertising messages.
\end{abstract}

Keywords: model, communication, messages, rational, emotional, advertising, discourse.
Resumen: Las nuevas Tecnologías de la Información, así como los cambios en el consumidor, han generado transformaciones en el enfoque estratégico publicitario. La comunicación racional, al estar centrada en el producto, busca la claridad, articulando beneficios claros y apoyándose en mecanismos estratégicos como la Unique Selling Proposition (USP) de Reeves. Por medio de este artículo, realizamos una revisión teórica sobre los modelos de comunicación racional y emocional resultantes si combinamos diferentes parámetros que dan como resultado nuevos discursos publicitarios. Para ello, combinaremos la parte teórica con ejemplos de casos galardonados en diferentes certámenes de Publicidad para comprender la delgada línea entre lo racional y emocional que tienen los mensajes publicitarios en la actualidad.

Keywords: Modelo; comunicación: mensajes; racional; emocional; publicidad; discurso.

IROCAMM.

\begin{tabular}{|l|l|l|}
\hline \multicolumn{1}{|c|}{ INTERNATIONAL } & REVIEW \\
\hline \multicolumn{1}{|c|}{ OF } & COMMUNICATION \\
\hline AND & MARKETING & MIX \\
\hline
\end{tabular}




\section{Introduction}

The differentiation between rational and emotional advertising is not so clear. When differentiating communication models within the rational discourse, different typologies can be distinguished. The Informative Rational model is the classic one in which the preference is given to the product, but there are also rational approaches which seek consumer complicity. Binet and Field (2012:63) talk about the Persuasive Rational model based on rational communication that uses emotional arguments to connect with the audience and make the benefit more attractive. This article suggests changing the denomination to Empathetic Rational, since qualifying it as persuasive isn't very definitive, for every model seeks to be persuasive.

The Emotional model also presents different communication models. In addition to the Classic Emotional that responds to the description of emotional communication, other models should be incorporated, such as the Social Creativity model, which actively seeks the generation of content that encourages participation and the brandconsumer connection, with propositions that encourage playing and participating. They are propositions that seek to gain space in earned media and that pursue generating conversation (Holt, 2004:36).

The Fame model was identified in 2008 in the IPA Awards study (Binet and Field, 2008:15) as an approach in which there is a complete abandonment of product communication. It pursues high notoriety communication that generates conversation, thus the brand gets higher consideration and standing.

The Emotional Cultural model is the most recent one which arises from the need for brands to gain relevance and esteem in an "adblocking" environment in which advertising is not well received (Holt \& Cameron, 2012:29). It works by giving visibility to consumer tensions and conflicts and by taking a position: family conciliation, children's education, the beauty industry pressure on what is the women's image. These last models (Social Creativity, Fame and Cultural) are aligned with the latest branding trends that advocate a communication that allows the consumer to participate and interact (Social Creativity), or it clearly goes for entertainment (Fame), or it develops from cultural tensions that worry the consumer (Cultural).

Finally, we must consider both the rational and emotional models when they use branded content solutions to generate interesting content for the consumer. 


\section{Rational versus Emotional Advertising}

The publicist David Berstein (1974:12) is one of the first authors to systematize the division between the two approaches, which were introduced in the world of pragmatics by Paul Simpson (2001:59). This drew attention to five parameters that serve to identify the two discourses (Martínez Camino, 2006:12, Farrán, 2013:78):

1. Direct vs. indirect communication: Rational advertising seeks to communicate the message in a simple and direct way, while emotional advertising does it in indirect ways.

"Rational messages have strong evidence of relevance that allows easy access in satisfactory contextual effects, while emotional messages communicate by insinuating instead of asking or reporting openly, forcing its recipient to a more arduous effort of contextualization to generate a set of weakly relevant implications. The prototypical emotional advertisement is the one that in some way raises the question of whether what is seen is an advertisement or not due to the use of a more suggestive than assertive language." (Martínez, 2006:68).

2. Facts vs. emotions: Rational advertising puts facts, physical, mechanical or clinical demonstrations and needs on the same level. Emotional advertising puts emotion, imagination, poetic truth and desires on the same level.

3. Clinical truth vs. poetic truth: The more rational the discourse, the more direct is the way to communicate it, for example, a scientifically or physically plausible and formally spectacular demonstration. The more emotional the discourse, the less direct it is.

4. Simple and clear presentation vs. a creative search of intrigue: If the messages are explained too much, the only reaction to expect is indifference. But if people are intrigued and the comprehension is not immediate, consumers have a reason to be attracted and even participate in the campaign.

5. Easy interpretation vs. difficult interpretation: A message which requires participation of the receiver works much better than one which treats him as someone who must simply absorb information.

A characteristic that defines rational ads is not so much what is said and shown as what is not said and not shown. This is the absolute absence of elements that depend on personal contexts, experiences or interpretative capacities of the reader, listener or spectator.

"In fact, to determine whether a communication is rational or emotional it would be enough with identifying who plays the major role in the communication: the product or 
the consumer. When the advertising idea has as reference the aspirations, desires and motivations of the consumer, the advertising is usually emotional. On the contrary, when we are talking about concrete benefits, the advertising usually proposes rational persuasive schemes. The simplest way to decide whether a communication is rational or emotional is with a simple question: Who are you talking about? If the answer is the brand, it is rational. It can be coated with different layers of emotions to be more persuasive, but it will still remain rational. In fact, a feature that partially defines rational advertising is the use of iconic elements that identify the brand. On the contrary, if it appeals to the consumer, if it speaks about frustrations, desires, motivations from his reality, it is an emotional campaign."(Vázquez, 2011:20)

One of the most common elements of rational advertising according to Simpson (2001:22) is the importance of giving visibility to both the brand and the selling proposal. Rational ads are summarized by the following facts:

- A prepared product location with the name of the brand visible and (if possible) the company logo

- A clear and unambiguous statement of the main reason of the product

Rational Advertising follows a clear style that summarizes the following structure in its discourse (Martínez Camino, 2006:56-58): if you want/need something, then you need this product. The objective of all ads that follow a rational discourse is to show the main reasons which encourage the purchase of a product or service (Simpson, 2001:23).

Rational advertising analyses the product's characteristics and contrasts the information. Its message focuses on the offer and gives arguments to try to convince the public to buy it. These arguments can be of different kinds:

- Deductive: A general principle makes the recipient deduce how the product will work.

- Rhetoric: The argument is based on rhetorical figures (metaphors, comparisons, etc.). A standard formula usually follows the following scheme: "This product is so... that...".

- Analogical: It uses similarity by comparing the product to another element that has the characteristics that we want to highlight.

Rational advertising owes much to Rosser Reeves' Unique Selling Proposition (USP) since it's an ideological mechanism. The idea of selling is considered to be the key to persuasion, which focuses on the product feature with the most potential of persuading the consumer. The arguments present the "reason why" (the benefit) in the most convincing way possible, for example:

- Maximize the benefit: "This product is so... that..."

- Problem solution schemes: "The problem of... will end with..."

- Discover and enhance the needs: "There are times when... you must have it." 
- The reason to believe: "It works..." and explaining how it works.

Uncertainty serves to differentiate the rational or emotional approach of a communication. This concept is managed differently depending on the type of advertising, as indicated by Martínez Camino (2006:45-52) who distinguishes:

- Generic uncertainty ("they are selling me something", "this is an ad")

- Substantial uncertainty (what do they want to sell us, in their own words)

- Argumentative uncertainty (why do I have to buy it)

Although Martínez Camino has a very transactional approach towards advertising (he thinks selling is the ultimate function of advertising, following Rossing Reeves' postulate), the concept of uncertainty is quite discriminating when it comes to differentiating the two kinds of advertising. The rational one seeks to eliminate uncertainty, clearing all kinds of doubts, while the emotional one plays with the uncertainty, with the expectations and interest of the viewer. The argumentative uncertainty, related to why we have to buy it, is found in the rational discourse, while in the emotional one it's often implicit and it does not get verbalized. In fact, this is seen more clearly when analyzing the parts of the advertisement, from which two different models emerge. In rational ads there is a prologue where the problem or need is introduced, and this gives way for the product to become the hero that solves the problem; this facilitates the reasons to buy the product. In emotional ads, the story begins in a strange context that is often not connected to the product that is going to be communicated at the end.

An example of this would be the BMW X3 Bruce Lee campaign, Grand Prize for Efficiency 2007. BMW's agency (SCPF) uses an interview with the actor where he introduces the concept "Be water, my friend" that establishes a context not linked to the product. This concept entered the popular culture becoming a catchphrase. It is at the end of the ad when the relationship with the product is clear and the uncertainty is eliminated: "Do not adapt to the road, be the road". The product hasn't appeared until that last moment, which is another feature of emotional campaigns which sometimes avoid deliberately the presence of the product, leaving it for the end. Prologue and exposure are elements that reduce uncertainty quickly while a strange element does just the opposite: increase it. Another example would be the Repsol campaign, "Let's Invent the Future" (2008) by Young \& Rubicam Spain, where an accumulation of seemingly disconnected inventions take place. ${ }^{1}$ During much of the 
TV ad, substantial uncertainty is found: what are they selling me? Only at the end do we know.

Similarly, the presence (or absence) of verbal language serves to minimize or amplify uncertainty. One example is the BMW "Hand" television commercial, the 2007 Grand Prize in the Premios a la Eficacia (Efficiency Awards) and was created by the publicist Toni Segarra, in which we find no speech until the end, when the brand appears.

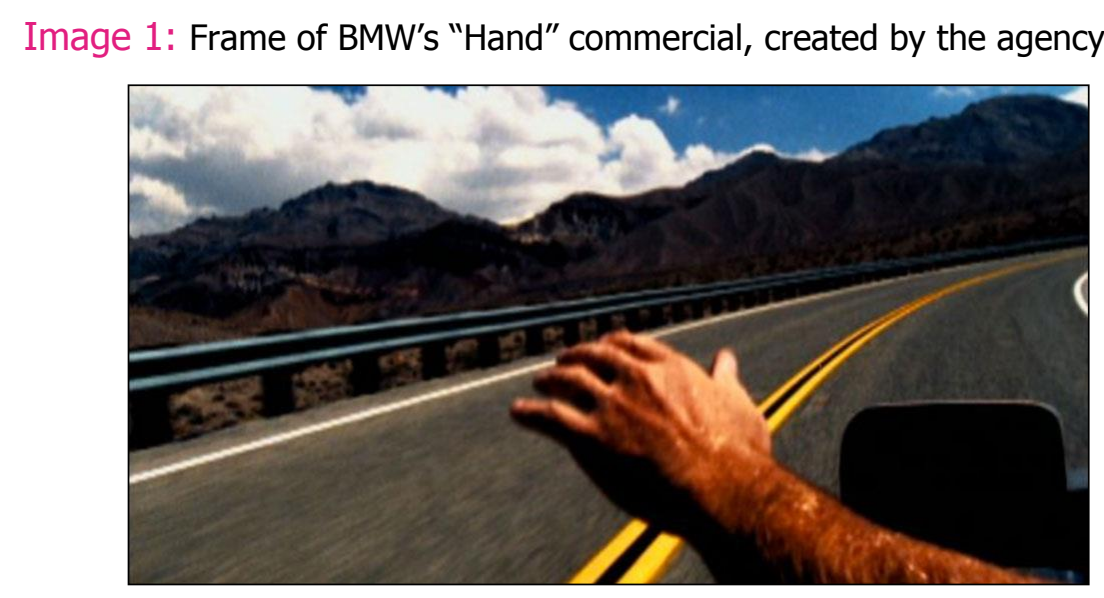

From: at https://www.youtube.com/watch?v=5wL__3xy4wo. Day of consultation: April 27, 2018

The absence of verbal language is a trait that can be identified with an emotional approach. We can see this aspect in many Audi campaigns, advertiser who received the award for brand track record in the Efficiency Awards in 2010. One of its most significant campaigns is "Dreams" for Audi A4, which is an example of total emphasis on different images of objects thanks to a communication lacking speech. The objects have a clear analogy with automotive elements and are accompanied by a song (a version of a Tom Waits theme) that builds a storyline of desire and aspiration to create a better version of oneself. The approach of the piece seeks recognition and identification from the viewer, appealing to their desire for improvement. 
Image 2: Frames of Audi A4's "Dreams" commercial, created by the agency Tandem DDB
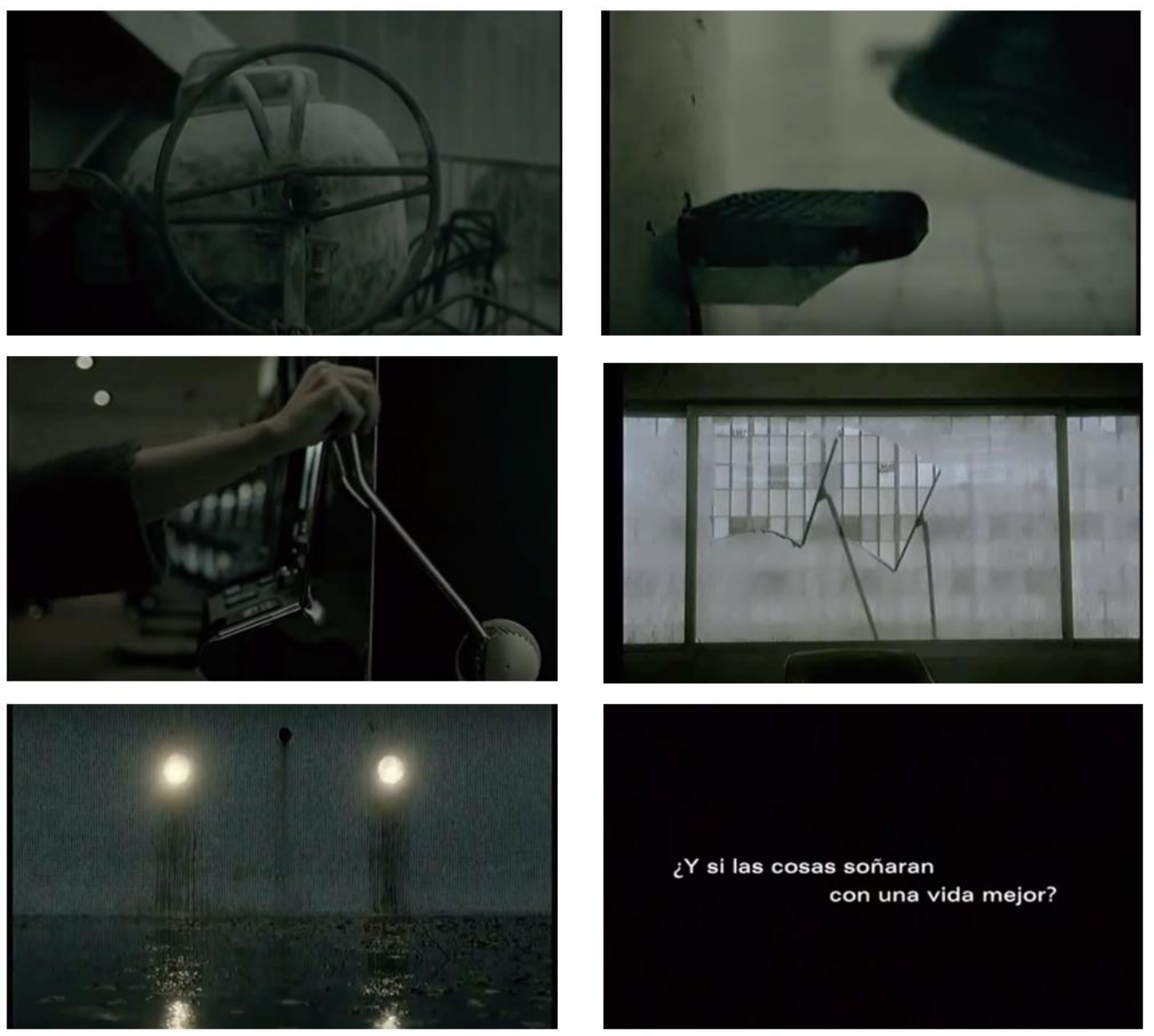

From: at https://www.youtube.com/watch?v=Ow4fCoVbKlw. Day of consultation: April 28, 2018

Emotional advertising requires an active interest on the receiver's part and a subjective effort to process information. Emotional advertising uses weak stimuli, which implies that any reader-listener-spectator must have enough inputs on their part to draw relevant conclusions. We are talking about weak stimuli that need elements such as perception or brand image, as pre-conceived and pre-loaded elements stored in the memory (Halliday, 1994:78; Simpson, 2001:27-32).

This last point highlights the importance of having a "memory of the track record of the brand", not of the brand itself. This is very important since emotional 
communication works on consumer truths that evolve and that can require the consumer to previously know the storyline from which it has been built. An example of this would be Aquarius' campaign "The human being is extraordinary", that is built from stories of amazing people like don Justo, a man who builds by himself a cathedral; Radio Colifata is a radio station whose broadcasters are patients from a psychiatric sanatorium in Buenos Aires; or people that were on the death row list in the United States but were released after proving their innocence and are now doing El Camino de Santiago. The relationship of all these stories with an isotonic drink is non-existent; the anchoring lies in the brand vision, consisted of created arguments that are not directly related to the product.

Image 3: Brand evolution according to Ollé and Riú's vision

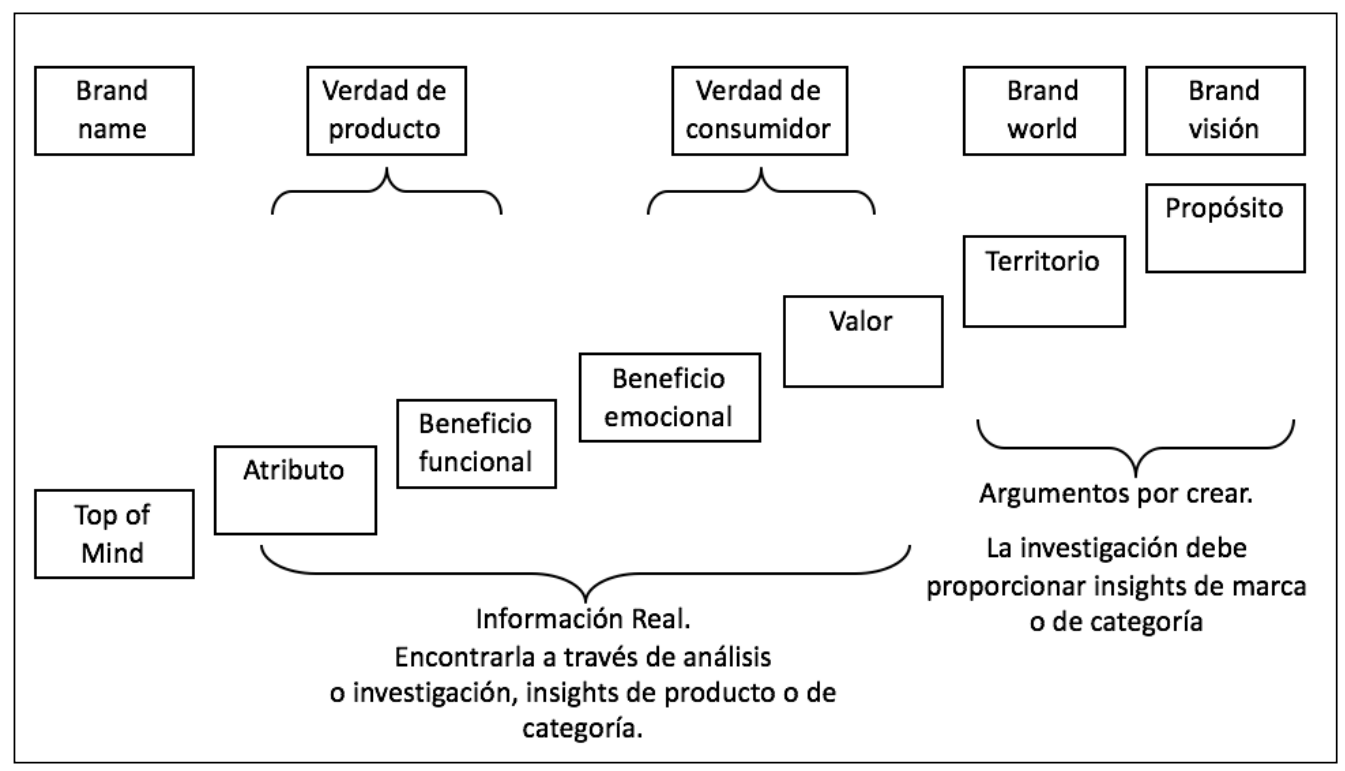

From: Ollé and Riú (2009): "New Brand Management. How to plant brands to grow businesses". Barcelona: Urano Editions

As we can see in the previous graph, as the evolution of the communication goes from the product scope, where the information is linked to functional attributes and benefits, to an emotional communication where the consumer has more importance, the discourse loses its connection with the reality of the product. This means that rational communication is easier to decode while emotional communication sometimes requires the consumer to have background information. 
In any case, it can be stated that emotional advertising is structured around a more elusive discourse, which means we cannot find references to the product nor a purchase reason. Its discourse invites the consumer-viewer-reader-listener to make a greater effort, pushing him to seek a personal interpretation of the sale proposition. In many cases, this interpretation can lead to reinterpreting the message, depending on the previous experience, the memory and the brand image of the individual (Pérez Tornero, 1982:36). Therefore, it may be that the ad isn't understood in its first broadcasts due to lack of specificity. On the other hand, a lack of specificity that requires of a greater involvement and reflection of the consumer.

We highlight this quality as another point to take into account when defining emotional advertising and differentiating it from rational advertising (Álvarez, 2008:11). Therefore, we can differentiate between:

- Confidence needs: confidence in oneself, security at home, at work...

We find it in many of the commercials from Banco Sabadell's "Conversations" campaign that hinged upon the idea of security and the future. Banco Sabadell is one of the most awarded advertisers in the Efficiency Awards.

- Affiliation needs: sense of belonging to a social group.

Multiple campaigns recognized in the Efficiency Awards work around this need, such as Campofrío's campaign "Everybody's curriculum", Grand Prize for Efficiency 2013, whose campaign's leitmotif is based on the reinforcement of the Spanish national pride by appealing to many of the things that make the country great. Gadis supermarket's campaigns, also awarded in the Efficiency Awards for the brand idea "Vivamos como Galegos!" (Let's live like Galicians!), claim the "galicianity" from a resilient and optimistic attitude using expressions that reflect a way of thinking, like "Maloserá", or "Se chove, que chova!" (If it rains, let it rain!).

- Esteem needs: need for high self-esteem and for social recognition.

- Need for self-fulfilment: need to feel happy with the goals proposed for oneself in life. 
Image 4: Frame of Gadis supermarket's "Vivamos como Galegos" campaign

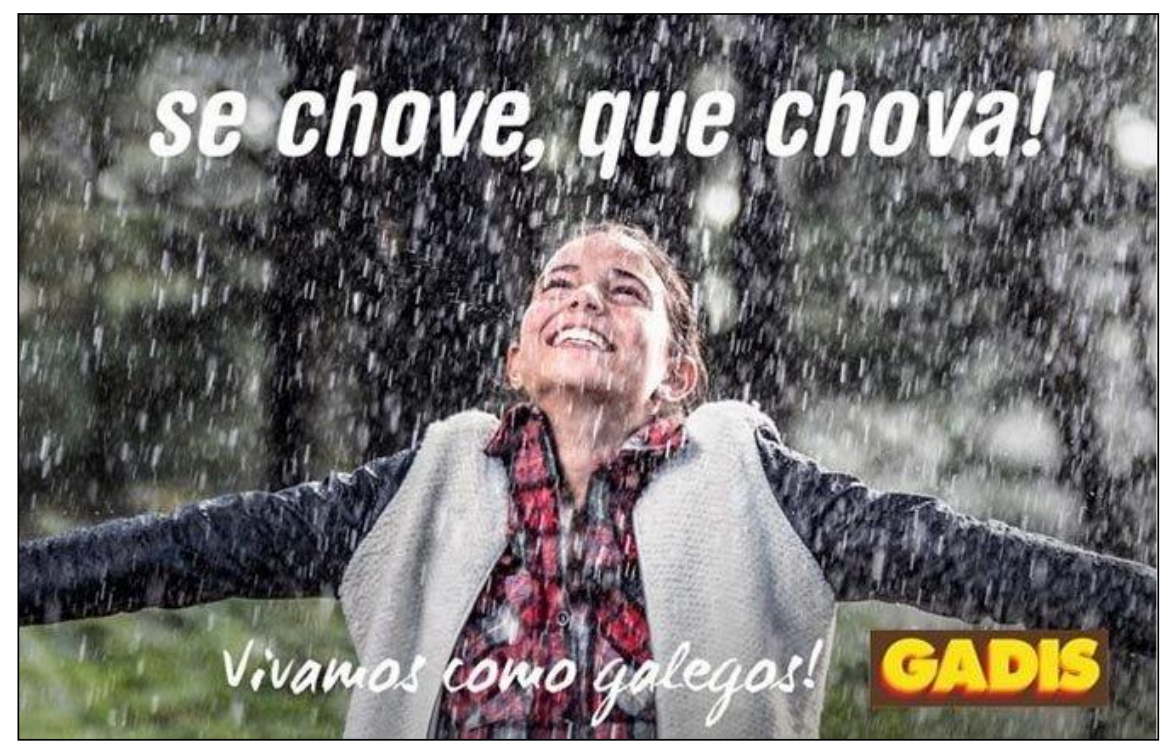

From: at https://www.youtube.com/watch?v=_jKK58hkG5s. Day of consultation: April 30, 2018

Given the lack of clarity in the division between emotional and rational advertising, since many times the communication is presented as a hybrid of both perspectives, new approaches are sought to classify this fact. Rossiter and Percy (1991:59) propose a classification between:

- Informational ads: They offer specific and relevant information about the product.

- Transformational ads: They associate consuming the brand with psychological characteristics that are not directly related to the product.

The latest evolution in communication is turning towards approaches that are more linked to the consumer (Regueira, 2012:63). This makes it harder to state whether the advertising discourse is rational or emotional. Feldwick (2008:74-79) distinguishes within rational advertising a Persuasive Rational model, which seeks to capture the attention and interest of the audience by presenting updates or information and adding an emotional element to it to make the message more memorable. The information may be presented in a way that challenges the perceptions belonging to the category or in a way that it enhances the ones of the brand. And again, the emotional part is a secondary element contingent to the rational part. 


\section{Social Creativity Model and Emotional}

\section{Fame Model}

The Emotional model evolves from the digital world's impact and the emergence of social media, which facilitate new possibilities of expanding dissemination and relevance. Authors such as Brymer (2009:59-63) emphasize on the social nature of communication and how people nowadays turn into media thanks to the digital medium and social networks. These people can give more pull to communication by boosting it. Concepts such as "herd" or "shoal" show the perspective in which the group is more important than the individual.

The term "Social Creativity" is coined by the agency DDB in 2008. The aforementioned Chuck Brymer, global CEO of DDB, relies on the "information cascade" phenomenon, generated when groups of people imitate the decisions that other people have taken before instead of deciding for themselves, to point out that when these "information cascades" are exploited by brands or by products and services, they can have enormous potential (Brymer, 2009:69-71). It's not enough to elaborate a message that simply reaches the individual, but one must aim for an intrinsically social communication with:

- Content that awaits a reaction and has a clear social interface.

- Content that encourages playing, participating and transmitting it.

- Content that connects people with each other, as well as people with brands.

- Content that builds brand communities.

The Fame model can be included in the Social Creativity one. It was identified in the IPA Awards (Binet and Field, 2008:65) and it's characterized for leaving aside the product scope to pursue the goal of becoming commented and shared pieces. From a methodological point of view, this approach is aligned with Sharch's thinking (1923:82):

- Brands are replaceable: All categories are comprised by a repertoire of brands in which you choose among a wide variety, of which any of them can easily meet the needs of the consumer.

- Penetration is key: Growth comes from attracting more consumers to the brand.

- The memory is fragile: People are constantly about to forget the brand. 
the same: communication has to offer interesting content that facilitates consumers to spread it and amplify its reach. These approaches take into account the growing lack of effectiveness of advertising and the power of the Internet as a medium where the viral effect is free. Some examples of this type of approach would be Old Spice's campaigns carried out by the agency Wieden \& Kennedy, being "The man your man could smell like" the best-known, winner of the Grand Television Prize of Cannes in 2010, and even of an Emmy (which in some ways underlines the entertainment component of creativity). The main TV commercial has 54 million viewings currently and the campaign as a whole reached 135 million views in its first year. Its following campaign got 5.9 million views on the first day, 11 million on the second and more than 20 million on the third. More importantly, it took the brand to the first position in the United States with an increase in sales of $125 \%$, place that it currently holds.

Image 5: Frame of Old Spice's "The man your man could smell like" commercial, created by the agency Wieden \& Kennedy

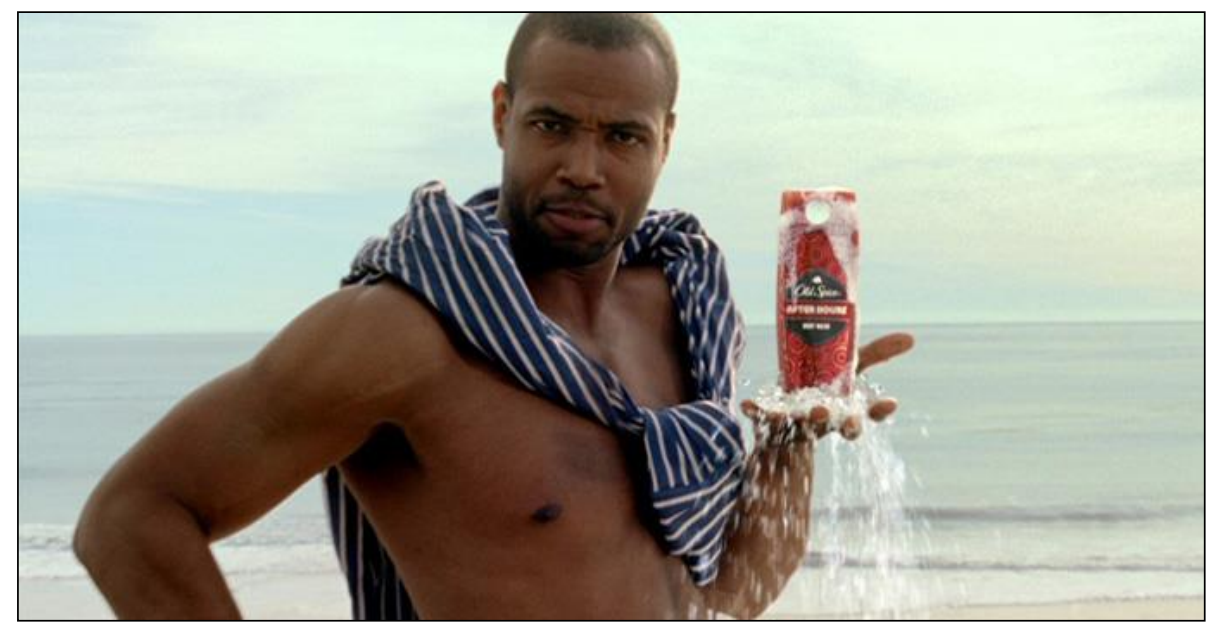

From: at https://www.youtube.com/watch?v=owGykVbfgUE. Day of consultation: April 15, 2018

\subsection{Emotional communication with a cultural approach: The Emotional Cultural model}

A survey conducted to British advertisers that was included in an Added Value study ${ }^{2}$

2 General conclusions available at the link verified on April 30, 2018: 
(2016) revealed that:

- $65 \%$ considered that being better connected to culture and assuming a cultural role could have a great impact in highlighting their brands.

- $83 \%$ considered that connecting with culture was a clear way to make their brand grow.

In a moment when it's hard for consumer brands to differentiate from each other, there is a movement for brands to provide cultural value, contributing with something meaningful, valuable and useful for their consumers. Brands that wonder how they can make people's lives better or easier by questioning what they value beyond their products and services, and by assessing where they have more credentials to act and their capabilities, have the resources to offer what is not directly related to their usual activity. Brands are more and more asking themselves how they can leave their mark in the world (Sutherland, 2010:21).

This is an important aspect since it's related to the brand purpose, which is the greater ambition that transcends the tangible part of the offer, and is in line with the contributions of Sinek (2011:53), who sought to connect with the consumer by appealing to their needs and deepest desires. This cultural discourse allows uniting the limits imposed by the categories and reinventing the way to connect with consumers. People stand up for their ideals and they experience stress when what they consider is different from the standards that society has imposed. The moment tensions appear, Holt (2004:185) points out it's the moment when the brand can come into play.

However, it is necessary that the brand action is rooted to its purpose, which is what allows it to have credentials- or consent- to take that position. This is gathered from a failed case, "Pepsi Refresh Project" (2010), which became a case study at Harvard 3 . Pepsi decided to leave the Superbowl, the biggest worldwide advertising event (112 million viewers and an advertising investment of more than 620 million dollars) to activate a cause marketing program with a 20 million dollar investment: the "Pepsi Refresh Project: Thirst for change". Consumers would be able to send propositions to get finance for causes related to health, environment, education and culture; the most voted ideas would get funding to come true. The action obtained a massive response with more than 80 million votes and 3.5 million Likes on its Facebook page (absolute success at social media level), but it failed at a commercial level: a $5 \%$ loss in market

http://av.ew.added-value.com/introducing-creating-cultural-value/.

3 Summary of the case at the link verified on April 30, 2018: http://www.hbs.edu/faculty/Pages/item.aspx?num=40954 
share, valued at 400 million dollars.

The campaign "Benditos Bares" (Blessed Bars) by Coca-Cola in Spain, Grand Prize 2014 in the Efficiency Awards, did manage the alignment between brand and cause. The connection between the tension and its link with the brand territory is what enabled Coca-Cola to defend the bars in a way that can be commercially optimized against the Pepsi case.

- Cultural tension: The financial crisis caused bars to close, which are a symbol of the way of understanding Spanish life.

- Cultural trend: defending of one's own. Affiliation to causes.

- Anchorage of the brand: happiness. Bars are associated to be a space where happiness is generated.

Other recognized campaigns in the Efficiency Awards, such as the Ikea Christmas campaign, also a Grand Prize (2015), use a similar approach. Under the insight expressed in a creative way "Christmas deconstructs our head" (appealing to expenses in food, gifts), which establishes the tension, the brand idea is expressed with the following: "Nothing like home to furnish our head", which is anchored to the vision of Ikea's founder, Ingvar Kamprad, who sees the home as the individual's formation space.

Image 6: Frame from Ikea's "Christmas deconstructs our heads" commercial

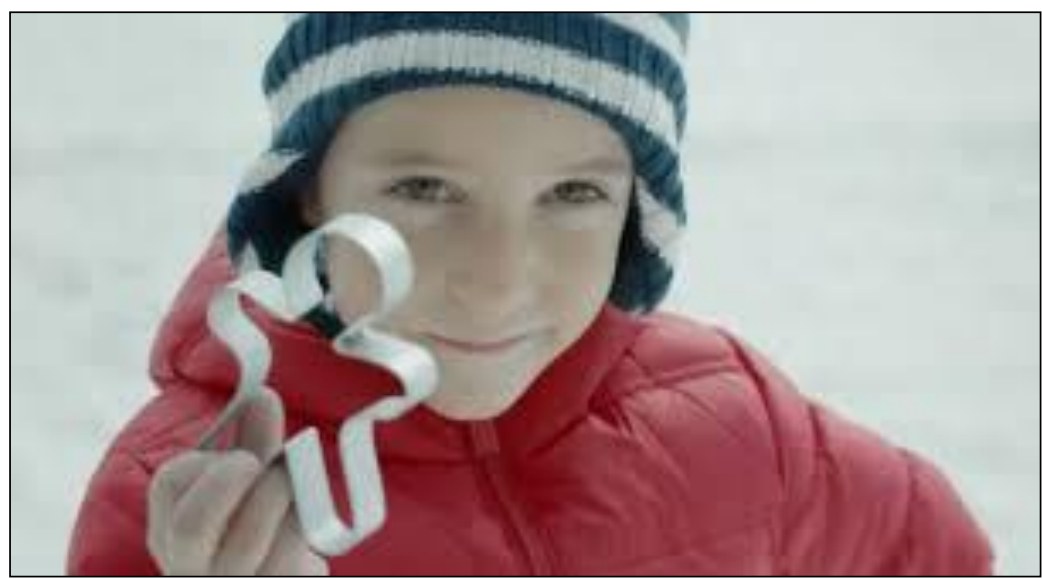

From: at https://www.youtube.com/watch?v=70qaoR6rSWM. Day of consultation: April 30, 2018

The Cultural model works on cultural insights, which are anchored in the context of culture, ideas, customs and social behaviors of a specific group of individuals that 
model their thoughts and feelings. The big difference compared to consumer insights is that the cultural ones offer a framework in which brand and consumer coexist, while the traditional insight is a consumer experience of which the brand takes advantage.

\section{Conclusions}

With this article, we have been able to prove how when making a distinction between rational and emotional advertising, it isn't so easy nor so fast. The main reason is that the distinction leads us to other communication models that need concrete parameters to be able to make the differentiation. Emotional communication reaches out further and includes other perspectives that come from the context in which the consumer from nowadays is developing in, generating that he becomes the thrust of the strategy of the brand. Sometimes, the consumer will interpret the message thanks to previous knowledge of the brand track record that provides clues for its understanding.

We are immersed in a moment of great change as a result of the rise of the Internet as a speaker of society and as a junction point between brands and consumers. This new scenario proves the need of including and defining previously the new emotional communication models, especially those linked to the culture and the context of consumers.

Emotion beats reason since it allows us to push the consumer into action: the appeal to society's feelings and emotions exerted by brands is what can generate a bond, especially if brands allow a space of interaction for consumers, a free space where you can contribute with content and brand experience. Therefore, the key lies in triggering emotional connections between brands and consumers, with collaborative, interactive and interesting content for society in general (in addition for the campaign target). This is the only way brands will be able to generate real and lasting engagement over time, thus building reputable and recognizable brands over time.

\section{Documentation}

Aaker, D. (2002). Construir marcas poderosas. Barcelona: Gestión 2000.

Álvarez Ruiz, A. (2012). La magia de planner. Madrid: ESIC.

Ariely, D. (2008). Las trampas del deseo. Barcelona: Ariel. 
Bernstein, D. (1974). Creative Advertising. London. Longman.

Binet, L. y Field, P. (2008). Marketing in the Era of Accountability. Henley-on-Thames: WARC.

Binet, L. y Field, P. (2012). Advertising Effectiveness; The long and short of it. London: IPA DataMine.

Brymer, C. (2009). The Nature of Marketing: Marketing to the Swarm as Well as the Herd. London: Palgrave Macmillan UK.

Farrán, E. (2013). Storytelling como herramienta y mejora de la eficacia en publicidad. Análisis de los casos Aquarius y BMW en televisión (1992-2010). Tesis Doctoral. Universitat Jaume I de Castelló.

Feldwick, P. (2015). Anatomy of Humbug. How to think differently about advertising. Leicestershire: Matador.

Halliday, M. (1994). An introduction to functional grammar. London: Arnold.

Holt, D. (2004). How brands become Icons: The principles of cultural branding. Boston: Harvard Business School.

Holt, D. y Cameron, D.(2012). Cultural Strategy: Using Innovative Ideologies to Build Breakthrough Brands. Oxford: Oxford University Press.

Martínez Camino , G. (2006). Diferenciación pragma lingüística de dos tipos de publicidad: Publicidad racional vs publicidad emocional. Santander: Universidad de Cantabria.

Nuñez, A. (2007) iSerá mejor que lo cuentesi Los relatos como herramientas de comunicación. Storytelling. Barcelona: Empresa Activa.

Ogilvy. D. (1984). Confesiones de un publicitario. Barcelona: Orbis.

Ogilvy, D. (1999). Ogilvy \& la publicidad. Barcelona: Folio.

Ollé, R. y Riu, D. (2009) El nuevo Brand Management. Cómo plantar marcas para hacer crecer negocios. Barcelona: Ediciones Urano.

Pérez Tornero, J.M. (1982). La semiótica de la publicidad. Barcelona: Editorial Mitre.

Quiñones, C. (2014). Desnudando la mente del consumidor. Consumer insights en el marketing. Barcelona: Gestión 2000.

Regueira, F. (2012). El contenido como herramienta eficaz de comunicación de marca. Análisis teórico y empírico. Tesis doctoral. Madrid: Universidad Rey Juan Carlos.

Rossiter, J.R., \& Percy, L. (1983). Visual communication in advertising, en R.J. Harris (ed.), Information processing research in advertising, Nueva York: Lawrence Hillsdale.

Sinek. S.(2011) Start with Why. London: Penguin.

Starch, D. (1923). Principles of advertising. Chicago: A.W.Shaw.

Steel, J. (2000). Truth, Lies \& Advertising. The art of account planning (Versión en Español). Madrid: Editorial Eresma \& Celeste Ediciones.

Simpson, P. (2001). Reason \&Tickle as pragmatic constructs in the discourse of advertising. Journal of pragmatics 33, Belfast, Northern Ireland: Queen's Univeristy Belfast, pp 589-607. 
Sutherland, R. (2010). Behavioural economics: A nudge in the right direction. Admap, March 2010, pp 20-23

Thomas Jr, G.M. (2004). Building the buzz in the hive mind. Journal of Consumer Behavior Volume 4, Issue 1, September 2004, pp 64-72.

Vázquez, P. (2011). El planner en la consecución de la eficacia publicitaria. En: Sánchez Blanco, C. (coordinadora) Planificación estratégica en España. Barcelona: Universitas.

Vaughn, R. (1980). How advertising works: a planning model. Journal of Advertising Research, 20(5), pp 27-33.

VVAA (2014). El libro de la eficacia. La publicidad que funciona. Los casos ganadores de la XVI edición de los premios a la eficacia en comunicación comercial. Madrid: Villena

NOTE: This article was made with the help of the research project entitled "The advertising business in the digital society: agency structure, professional profiles and new creative trends" directed by Professor Cristina González Oñate. Project code P1-1B2015-27; Research P 